\title{
Candida ESOPHAGITIS: SPECIES DISTRIBUTION AND RISK FACTORS FOR INFECTION
}

\author{
Dimas Alexandre KLIEMAnN(1), Alessandro Comarú PASQUAlotTO(1,2), Maicon FALAVIGNA(3), Thiane GIARETTA(4) \& Luiz Carlos SEVERO(1,4,5)
}

\begin{abstract}
SUMMARY
Although Candida albicans is the main cause of fungal esophagitis, other species such as C. tropicalis, C. krusei and C. stellatoidea have also been implicated. Several studies have identified risk factors for C. albicans esophagitis. However, data for non-C. albicans species is still sparse. The aim of this study was to determine the etiology of Candida esophagitis in our medical centre over an 18-month period. Additionally, we aimed to investigate predisposing conditions for esophageal candidosis caused by different Candida species. A total of 21,248 upper gastroscopies were performed in Santa Casa Complexo Hospitalar between January 2005 and July 2006. The prevalence of Candida esophagitis was $0.74 \%(\mathrm{n}=158)$. C. albicans caused the vast majority of infections (96.2\%), followed by $C$. tropicalis $(2.5 \%)$, C. lusitaniae $(0.6 \%)$ and C. glabrata $(0.6 \%)$. There were 81 women $(51.3 \%)$ and 77 men $(48.7 \%)$. No case of mixed infection occurred. Concomitant oral candidosis was documented for $10.8 \%(\mathrm{n}=17)$. Most of cases $(55.1 \%)$ involved outpatients. Around one fifth of patients in our cohort had no identifiable risk factors for esophageal candidosis (20.8\%). Since nearly all infections were caused by $C$. albicans we were not able to determine risk factors for esophagitis caused by other Candida species.
\end{abstract}

KEYWORDS: Candida; Opportunistic infections; Esophagitis; Endoscopy; Risk factors; Yeasts.

\section{INTRODUCTION}

Candida species are the most common agents of fungal esophagitis. While this is usually caused by $C$. albicans ${ }^{21}$, other species such as C. tropicalis, $C$. krusei and C. stellatoidea have also been involved ${ }^{16}$. Risk factors for Candida esophagitis have been documented in several series. These include pharmacological suppression of gastric acid production ${ }^{1,2,13}$, use of antibiotics ${ }^{24,28}$, previous vagotomy ${ }^{4,7,8}$, functional or mechanical esophageal abnormalities ${ }^{28,30}$, and endocrine diseases such as diabetes mellitus, hypothyroidism and hypoparathyroidism ${ }^{11,18}$. Malnutrition, alcoholism, advanced age ${ }^{26,27,28}$, and therapy with corticosteroids - either systemic or inhaled - has also been implicated ${ }^{2,22}$. However, there are very limited data from Brazilian patients. In addition, very little is known for infections caused by species other than C. albicans. This study aims to document the species distribution in patients with Candida esophagitis over an 18-month period (2005-2006) in a single medical centre. We were particularly interested in the comparison of risk factors for esophageal candidosis amongst patients infected by different Candida species.

\section{MATERIAL AND METHODS}

This study was performed between January 2005 and July 2006 at Santa Casa Complexo Hospitalar, an university tertiary hospital with 1,200 beds located in Porto Alegre, Southern Brazil. Esophageal candidosis was defined by the recovery of Candida species from either esophageal brushing or a biopsy of the esophagus performed during upper gastroscopy. Esophageal candidosis was endoscopically confirmed in the presence of typical sparse or coalescent white plates covering the esophageal mucosa. Only cases of endoscopically-confirmed Candida esophagitis were included, so patients considered to be only colonized by Candida species were excluded. Since this was a retrospective study, neither clinical symptoms nor reason for performing endoscopy was evaluated. All samples obtained endoscopically were sent in saline solution to the Mycology laboratory. The germ tube test was used to differentiate C. albicans from other Candida species, which were in turn identified with ID 32C (bioMérieux Marcy l'Étoile, France).

Medical records of patients with Candida esophagitis, were reviewed to identify potential risk factors for the infections, presented in the 30 days preceding the endoscopic procedure. Chronic therapy with corticosteroids was considered when patients were in use of $20 \mathrm{mg}$ of prednisone of equivalent for $>14$ days.

Statistical analysis was performed with SPSS software. Categorical variables were compared using the chi-square and the Fisher's exact tests, and $p$ values $\leq 0.05$ were considered statistically significant. The study received ethical approval by the hospital's research ethic board (protocol number1000/05).

(1) Programa de Pós-Graduação em Ciências Pneumológicas, Universidade Federal do Rio Grande do Sul, Porto Alegre, RS, Brasil.

(2) Pesquisador nível 2 do CNPq (Conselho Nacional de Desenvolvimento Científico e Tecnológico), Brasil.

(3) Faculdade de Medicina, UFRGS, Porto Alegre, RS, Brasil.

(4) Departamento de Medicina Interna, Faculdade de Medicina, UFRGS, Porto Alegre, RS, Brasil

(5) Pesquisador nível 1 B do CNPq, Brasil.

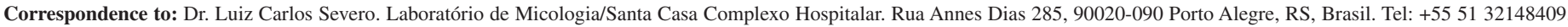
E-mail: severo@santacasa.tche.br 
KLIEMANN, D.A.; PASQUALOTTO, A.C.; FALAVIGNA, M.; GIARETTA, T. \& SEVERO, L.C. - Candida esophagitis: species distribution and risk factors for infection. Rev. Inst. Med. trop. S. Paulo, 50(5): 261-263, 2008.

Table 1

Distribution of patients infected with Candida albicans or other Candida species according to risk factors for esophageal candidosis

\begin{tabular}{lccc}
\hline \multirow{2}{*}{ Risk factor } & \multicolumn{2}{c}{ Candida species involved } & \multirow{2}{*}{$p$ value } \\
\cline { 2 - 3 } Any identifiable risk factor & C. albicans $(\mathrm{n}=152)$ & Other Candida species (n=6) & 0.098 \\
Proton pump inhibitor or H2 blocker & $80.9 \%$ & $50.0 \%$ & 0.681 \\
Age $\geq$ 65 years & $39.1 \%$ & $50.0 \%$ & 0.404 \\
Use of antibiotics & $37.7 \%$ & $16.7 \%$ & 0.666 \\
Solid cancer & $35.8 \%$ & $16.7 \%$ & 0.342 \\
Diabetes mellitus & $22.4 \%$ & $0.0 \%$ & 0.591 \\
Long term therapy with corticosteroid & $17.8 \%$ & $0.0 \%$ & 0.486 \\
Chronic renal failure & $10.1 \%$ & $16.7 \%$ & 1.000 \\
HIV infection & $7.9 \%$ & $0.0 \%$ & 1.000 \\
Inhaled corticosteroid & $7.2 \%$ & $0.0 \%$ & 0.360 \\
Use of another immunosuppressive agent & $6.7 \%$ & $16.7 \%$ & 1.000 \\
\hline
\end{tabular}

\section{RESULTS}

During the period of study 21,248 upper gastrointestinal endoscopies were performed in our medical centre. The prevalence of fungal esophagitis was $0.8 \%(n=163)$. Five patients were excluded - four due to lack of clinical data and one because the infection was caused by Saccharomyces cerevisae. The vast majority of infections for the remaining 158 patients were caused by $C$. albicans $(96.2 \%)$, followed by C. tropicalis $(2.5 \%)$, C. lusitaniae $(0.6 \%)$ and C. glabrata $(0.6 \%)$. There were 81 women $(51.3 \%)$ and 77 men $(48.7 \%)$. All patients were adults, with ages ranging from 21-88 years old (mean 57.4; standard deviation 16.7 years). No case of mixed fungal infection occurred. Concomitant oral candidosis was documented for $10.8 \%(\mathrm{n}=17)$. Most of cases $(55.1 \%)$ involved outpatients.

The majority of patients $(79.2 \%)$ had at least one identifiable risk factor for esophageal candidosis. Median number of risk factors per patient was 1.0 (range, 1-6). As shown in Table 1, no difference was observed in the distribution of risk factors for esophageal candidosis when Candida species were considered.

\section{DISCUSSION}

The prevalence of fungal esophagitis in this study involving 21,248 patients submitted to upper gastrointestinal endoscopy was $0.77 \%$. Similar frequencies have been reported in other series ${ }^{14,17,25}$. We observed in our study that virtually all cases of fungal esophagitis were caused by Candida species, with one rare case due to S. cerevisae.

Although esophageal candidosis is a common opportunistic infection in patients infected by the human immunodeficiency virus (HIV) ${ }^{23}$, the vast majority of patients in our series $(93.7 \%)$ were not infected by this virus. Since this was a retrospective study, the importance of this variable might be underestimated. However, other authors have demonstrated a marked reduction in the prevalence of esophageal candidosis in HIV patients over the last decade, justified by the immunological benefit obtained from antiretroviral therapy ${ }^{10,15,19}$.

Around one fifth of patients in our cohort had no identifiable risk factors for esophageal candidosis $(20.8 \%)$. It has been demonstrated that esophageal candidosis can occur in healthy individuals ${ }^{14}$. Still the mechanisms of infection in these patients are not clear ${ }^{6,16}$. Candida species are known to colonize the esophagus of $20 \%$ of healthy adults ${ }^{12,22}$. In the series by MIMIDIS et al., $36 \%$ of patients had no evident risk factor for esophageal candidosis ${ }^{14}$. Interestingly, we observed that $50 \%$ of patients infected by species other than C. albicans showed no evident predisposing condition for the infection. Due to the limited number of patients with non-C. albicans infection $(n=6)$, we were not able to show any difference of statistical significance. The clinical or biological importance of this, however, is unknown. In addition it should be noted that, due to the retrospective nature of our study, some data may be missing. In particular, immunological or endocrine conditions predisposing patients to chronic mucocutaneous candidosis were not systematically investigated ${ }^{20}$.

In conclusion, we found $C$. albicans to be the main etiology of fugal esophagitis in our medical centre. Most of patients had one evident predisposing condition for Candida esophagitis, and HIV infection was quite uncommon. The occurrence of non-C. albicans infections in patients with no obvious risk factors for these conditions deserves further investigation.

\section{RESUMO}

\section{Esofagite por Candida: distribuição da espécie e fatores de risco para a infecção}

Embora Candida albicans seja a principal causa de esofagite fúngica, outras espécies como $C$. tropicalis, $C$. krusei e $C$. stellatoidea também têm sido implicadas. O objetivo desse estudo foi descrever espécies causadoras de esofagite fúngica em nosso centro durante um período de 

trop. S. Paulo, 50(5): 261-263, 2008.

18 meses, além de comparar condições predisponentes para candidose esofágica causadas por diferentes espécies de Candida. De janeiro de 2005 a julho de 2006, 21.248 endoscopias digestivas altas foram realizadas no Complexo Hospitalar Santa Casa (Porto Alegre, Brasil). A prevalência de esofagite por Candida foi de $0,74 \%(\mathrm{n}=158)$. $C$. albicans foi a causadora da maioria das infecções $(96,2 \%)$, seguida por $C$. tropicalis $(2,5 \%)$, C. lusitaniae $(0,6 \%)$ e C. glabrata $(0,6 \%)$. Candidose oral concomitante foi documentada em $10,8 \%(n=17)$. Cerca de $21 \%$ dos pacientes não teve qualquer fator de risco identificável para candidose esofágica. Em função do pequeno número de pacientes infectados por espécies não-Candida albicans, não foi possível determinarmos fatores de risco para estas infecções.

\section{REFERENCES}

1. BADARINARAYANAN, G.; GOWRISANKAR, R. \& MUTHULAKSHMI, K. Esophageal candidiasis in non-imune suppressed patients in a semi-urban town, southern India. Mycopathologia, 149: 1-4, 2000.

2. BAEHR, P.H. \& McDONALD, G.B. - Esophageal infections: risk factors, presentation, diagnosis, and treatment. Gastroenterology, 106: 509-532, 1994

3. BONACINI, M.; YOUNG, T. \& LAINE, L. - The causes of esophageal symptoms in human immunodeficiency virus infection. A prospective study of 110 patients. Arch. intern. Med., 151: 1567-1572, 1991.

4. BROOKS, J.R.; SMITH, H.F. \& PEASE Jr., F.B. - Bacteriology of the stomach immediately following vagotomy: the growth of Candida albicans. Ann. Surg., 179: $859-862,1974$

5. CONNOLlY, G.M.; HAWKINS, D.; HARCOURT-WEBSTER, J.N. et al. Oesophageal symptoms, their causes, treatment, and prognosis in patients with the acquired immunodeficiency syndrome. Gut, 30: 1033-1039, 1989.

6. HOSHIKA, K.; IIDA, M. \& MINE, H. - Esophageal Candida infection and adherence mechanisms in the nonimmunocompromised rabbit. J. Gastroent., 31: 307-313, 1996.

7. KARMELI, Y.; STALNIKOWITZ, R.; ELIAKIM, R \& RAHAV, G. - Conventional dose of omeprazole alters gastric flora. Dig. Dis. Sci., 40: 2070-2073, 1995.

8. KOCHHAR, R.; TALWAR, P.; SINGH, S. \& MEHTA, S.K. - Invasive candidiasis following cimetidine therapy. Amer. J. Gastroent., 83: 102-103, 1988.

9. LAINE, L. \& BONACINI, M. - Esophageal disease in human immunodeficiency virus infection. Arch. intern. Med., 154: 1577-1582, 1994.

10. MARR, K.A. - Invasive Candida infections: the changing epidemiology. Oncology, 18(14 suppl. 13): 9-14, 2004.

11. MATHIESON, R. \& DUTTA, S.K. - Candida esophagitis. Dig. Dis. Sci., 28: 365$370,1983$.

12. MAVOR, A.L.; THEWES, S. \& HUBE, B. - Systemic fungal infections caused by Candida species: epidemiology, infection process and virulence attributes. Curr. Drug Targets, 6: 863-874, 2005.

13. McDONALD, G. - Esophageal disease caused by infection, systemic illness, medication and trauma. In: SLEISENGER, M.H. \& FORDTRAN, J.S. Gastrointestinal disease. Philadelphia, W.B. Saunders, 1993. p. 427-455.
14. MIMIDIS, K.; PAPADOPOULOS, V.; MARGARITIS, V. et al. - Predisposing factors and clinical symptoms in HIV-negative patients with Candida oesophagitis: are they always present? Int. J. clin. Pract., 59: 210-213, 2005.

15. MOCROFT, A.; OANCEA, C.; VAN LUNZEN, J. et al. - Decline in esophageal candidiasis and use of antimycotics in European patients with HIV. Amer. J. Gastroent., 100: 1446-1454, 2005.

16. NAITO, Y.; YOSHIKAWA, T.; OYAMADA, H. et al. - Esophageal candidiasis. Gastroent. Jap., 23: 363-370, 1988.

17. OLMOS, M.A.; ARAYA, V.; CONCETTI, H. et al. - Oesophageal candidiasis: clinical and mycological analysis. Acta Gastroent. lat.-amer., 35: 211-218, 2005.

18. PHAOSAWASDI, K.; RICE, P. \& LEE, B. - Primary and secondary Candida esophagitis. IMJ. Ill. med. J., 169: 361-365, 1986.

19. RAUFMAN, J.P. - Declining gastrointestinal opportunistic infections in HIV-infected persons: a triumph of science and a challenge for our HAARTs and minds. Amer. J. Gastroent., 100: 1455-1458, 2005.

20. ROSA, D.D.; PASQUALOTTO, A.C. \& DENNING, D.W. - Chronic mucocutaneous candidiasis and oesophageal cancer. Med. Mycol., 28: 1-7, 2007.

21. SANT'ANA, P.D.L; MILAN, E.P.; MARTINEZ, R. et al. - Multicenter Brazilian study of oral Candida species isolated from AIDS patients. Mem. Inst. Oswaldo Cruz, 97: 253-257, 2002.

22. SIMON, M.R.; HOUSER, W.L.; SMITH, K.A. et al. - Esophageal candidiasis as a complication of inhaled corticosteroids. Ann. Allergy Asthma Immunol., 79: 333338,1997 .

23. SIMS, C.R.; OSTROSKY-ZEICHNER, L. \& REX, J.H. - Invasive candidiasis in immunocompromised hospitalized patients. Arch. med. Res., 36: 660-671, 2005.

24. THAPA, B.R. \& KUMAR, L. - Candida esophagitis after antibiotic use. Indian J. Pediat., 56: 296-299, 1989.

25. UNDERWOOD, J.A.; WILLIAMS, J.W. \& KEATE, R.F. - Clinical findings and risk factors for Candida esophagitis in outpatients. Dis. Esophagus, 16: 66-69, 2003.

26. VERMEERSCH, B.; RYSSELAERE, M.; DEKEYSER, K. et al. - Fungal colonization of the esophagus. Amer. J. Gastroent., 84: 1079-1083, 1989.

27. WEERASURIYA, N. \& SNAPE, J. - A study of Candida esophagitis in elderly patients attending a district general hospital in the UK. Dis. Esophagus, 19: 189-192, 2006.

28. WILCOX, C.M. \& KAROWE, M.W. - Esophageal infections: etiology, diagnosis, and management. Gastroenterologist, 2: 188-206, 1994.

29. YAKOOB, J.; JAFRI, W.; ABID, S. et al. - Candida esophagitis: risk factors in nonHIV population in Pakistan. Wld J. Gastroent., 9: 2328-2331, 2003.

30. YEE, J. \& WALL, S.D. - Infectious esophagitis. Radiol. Clin. N. Amer., 32: 11351145,1994

Received: 22 February 2008

Accepted: 27 August 2008 